\title{
Leadership by Example: A Theological Discourse on Humility
}

\begin{abstract}
Humility is one of the virtues required for leadership in all sectors of life. It is clearly demonstrated in the Bible in various forms by the various leaders raised by God. Among the many signs of demonstration is the feet washing undertaken by Jesus for his disciples. Through this, He recommends his followers to emulate in their leadership responsibilities. This paper is a critical study of the text John 13:4-5. The theological discourse method was used on humility which must be a coveted virtue in leadership by example today. It means letting God use both your strengths and weaknesses to accomplish His will and glorify His name. Thus, the text will be looked at with a critical lens to come out with the intent of the text. The study reveals that any leader who wants to be successful must be humble. The paper recommends that leaders should examine themselves and find out the kind of leadership style they are exhibiting for their followers.
\end{abstract}

Keywords: reward power leadership, coercive power, legitimate power, expert power leadership, referent power

\author{
LIVINGSTONE YAO TORSU \& \\ PHILIP QUACOE-TAKRAMA \\ ${ }^{1}$ Livingstone Yao Torsu is an Assistant \\ Lecturer in the Department of Theology, \\ Heritage Christian College, Accra- Ghana. \\ Email: rev.livingstoneyaotorsu@yahoo.com \\ Philip Quacoe-Takrama, is a Tutor at \\ the Sefwi-Wiawso College of Education, \\ Department of Social Science and PhD \\ Student of University of Cape Coast, Ghana. \\ Email:philipquacoe49@gmail.com.
}

\section{Manuscript}

Received 11th May 2020,

Accepted 17th June 2020,

Published online 29th June 2020.

\section{INTRODUCTION}

Humility, or being humble is, the defining characteristic of an unpretentious and modest person, someone who does not think that he or she is better or more important than others. "The term humility is from the Latin humilis, which is translated not only as humble but also alternatively as "low" or from "from the earth; and humus." Because the concept of humility addresses futuristic self-worth, it is emphasized in the realm of religious practice and ethics where the motion is often made more precise and extensive."2 Humility as a religious or spiritual virtue is different from the act of humiliation or shaming though the former may follow as a consequence of the latter. ${ }^{3}$ Humility is defined as a quality by which a person considering his own defects has a humble opinion of himself and willingly submits to God and to others for God's sake. St. Bernard defines it as "a virtue by which a man knowing himself as he truly is abases himself" True humility is distinctly different from false humility which consists of deprecating one's own sanctity, gifts, talents and compliments for the sake of receiving praises or adulation from others. Clearly the key to understanding Christian leadership requires learning to lead like Jesus. In Matt .11: 25-30, Jesus describes his leadership as gentle and humble. In the chapter that follows, he quotes from Isaiah 42 to describe the chosen servant as one who "will not quarrel or cry out; no one will hear his voice in the streets. A bruised reed he will not break and a smoldering wick he will not snuff out" (Matt 12: 19-20a).

\section{Leadership Diversities}

It has been said that humility is the hallmark of great leaders5. According to Dunn, "Jesus stooped so low as a servant with all humility to serve." ${ }^{\prime 6}$ More importantly is the observation made by Weiss that Jesus' act of humility is a symbolic

\footnotetext{
"Humility", accessed on June 11, 2020, www.merriam-webster.com

Ibid.

http://en.wikipedia.ogr/wiki/humility accessed on Wednesday, October 22, 2019.

http://profmsr.blogspot.com accessed on Thursday, June 11, 2020.

J.D.G.Dunn, The Washing of the Disciples' Feet in John 1361 (1970): 247.
} 
representation of the cleansing effect, his death would have for humans defiled by $\sin ^{7}{ }^{7}$ The above observation by Weiss therefore further strengthens the act of the foot washing in servant leadership. The need for all to emulate this virtue of humility could not have come at an opportune time than now, in a world where such a virtue is considered as weakness, for self-pride has been enthroned instead. Humility, furthermore, is for the strong and mature not for the weak and immature. Therefore, humility is a unique virtue for successful leadership.

Leadership is "the ability of an individual to influence, motivate and enable others to contribute towards the effectiveness and success of an organization." ${ }^{8}$ Leadership is not the property of the leader as George Binney has argued, nor as some have suggested of the followers. George Binney sees leadership as: what happens between people in a particular moment. Leadership is a social process, the result of interactions between and within individuals and groups. It is both very personal and the product of groups and overall interest of business and organizational context. ${ }^{9}$ According to Gary Yukl, the sources of leadership are numerous and are as follows:

Reward Power Leadership. This is the type of leadership where the target person complies in order to obtain rewards controlled by the agent; in this case the source of authority is mostly the employer of the agent. ${ }^{10}$

Coercive Power: Is the type of leadership where the target person complies in order to avoid punishment controlled by the agent, the source of the authority here may be parental or otherwise.

Legitimate Power: Source of authority here is the constitution or God. The target person complies because he/she believes the agent has the right to make the request and the target person has the obligation to comply. ${ }^{11}$

Expert Power Leadership: The target person complies because he/she believes that the agent has special knowledge about the best way to do something. The source of authority is mostly educational or professional skills. ${ }^{12}$

Referent Power: The target person complies because he/she admires or identifies with the agent and wants to gain the agent's approval. ${ }^{13}$ A typical example is a master-apprentice relationship.

All the types of leadership mentioned above are important because one needs to know them in order to appreciate the uniqueness of servant leadership.

\section{Biblical concept of Leadership (John 13: 4-5.) \\ Washing of the Feet}

Verse 4. So he rose from the table, took off his outer garment; and tied a towel around his waist, 5. Then he poured some water into a basin and began to wash the disciples'feet and dry them with the towel around his waist. Vv. 4-5. He rose from supper, and laid aside his garments and took a towel, and girded himself (NRSV).

\section{a. took off his outer garment (v.4)}

Literally "laid down"; this is the same verb tithe used in 10:11, 15, 17, 18 for the laying down of life. A deliberate parallel is not out of the question since the corresponding action of taking up (both the robe and life) is also expressed by one verb lambanein in 13:12 and 10:17, 18. All of this serves to relate the feet washing to the death of the Lord. ${ }^{14}$ David Ellis said by this act Jesus pictures the humiliation which, in its fullest expression, meant for him the laying down of his life. Obviously therefore, Christ's humility was greatly seen at this point, though he is God yet served with the greatest of ease due to his humility. There can be no further allegorical significance than this, and to look for it is to overlook verse 15 which plainly states the act was primarily an exemplary one. And that Jesus took the slave's posture, when he took the towel, which indeed he adopted supremely as the Servant of the Lord. ${ }^{15}$ The description of his "laying aside" and later "taking up" his garments recalls the image of Jesus the Good shepherd, who is able to "lay aside" (10:11-18) and "take up" his life (10:17-18). ${ }^{16}$

\footnotetext{
H. Weiss, 'Foot Washing in the Johannine Community' 21, NOVT, (1979): 299.

Gary Yukl, Leadership in Organization (University of New York: Pearson Hall, 2005), 2.

9 George Binney, et al, Living Leadership: A Practical Guide for Ordinary Heroes (Great Britain: Prentice Hall, 2005$), 6$.

10 https://expertprogrammanagement.com/2017/06/the-5-types-of-power/ accessed on Saturday March 30, 2020.

11 Ibid.

12 Ibid.

13 Gary Yukl, Leadership in Organization, 4.

${ }_{14}$ Mary L. Coloe, "Welcome to the Household of God: The Foot Washing in John 13" in The Catholic Biblical Quarterly 66, no.3, (2004): 400-15.

15 David J. Ellis, New International Commentary, 1253.

16 Ellis, New International Commentary, 551.
} 
Dunn states that in the ancient Near East, where roads were dusty, and sandals were the common footwear, making provision for guests or travelers to wash their feet was an act of common hospitality but was quick to add "Jesus stooped so low as a servant with all humility to serve." ${ }^{17}$ Some commentators view Jesus' act, according to H. Weiss, as a symbolic representation of the cleansing effect his death would have for humans defiled by $\sin .{ }^{18}$ Raymond E. Brown states that, Jesus girds himself like a servant as is the case in Lk 12:37, 17:8. ${ }^{19} \mathrm{~A}$ true servant as Jesus was has no shame of even the meanest of Jobs, but is ready to do whatever provided it is in God's will, this path his followers must thread and it is the path of humility.

J. N. Collins noted that Jesus at the feet washing was bringing into fulfillment Mark 10:43-45 which he had made reference to earlier, "whoever wishes to become great among you must be your servant... for the son of man came not to be served but to serve." ${ }^{20}$ A similar argument was put forward by David Noel Freeman, that the more one desires to lead, the more he must be prepared to serve others. ${ }^{21}$ Barrett states that over against Jesus stands Judas Iscariot, now fully in the hands of Satan. In full awareness of the total condition; Jesus proceeds to perform the menial task of washing his disciples' feet. ${ }^{22}$

\section{b. The basin (v.5)}

Literally "the pitcher". The article shows that the vessel is a normal utensil for the meal. Brown quoted Jeremias who sees the use of the article as one of the numerous Semitisms in these verses. Outside of this passage the word nipter occurs only in a Cyprian inscription from Roman times; but since niptein means "to wash", it is a vessel for washing (the -ter, suffix is instrumental). In the Ancient Near East washing was not normally done in a basin of standing water but by pouring water over the parts of the body (II Kings $3: 11$ ). ${ }^{23}$

\section{c. Wash the disciples'feet (v.5)}

The Lord here indicated he has come indeed to serve and, not to be served. One word to qualify this is humble service, which is an identity of all servants everywhere. Jesus acts with a solemn and deliberate gesture towards the disciples. Laying aside his clothes and girding himself with a towel, he washes the feet of the disciples. ${ }^{24}$ Jesus here demonstrated the quality of humility, which best identities a servant, which he truly was. Servant leaders must imitate this in their quest to serve. Many events in the New Testament occasioned the washing of feet. According to Arland J. Hultgren, the occasions included (1) cultic settings (2) domestic setting for personal hygiene and comfort, and (3) domestic settings devoted to hospitality. ${ }^{25}$ But none of the above reasons captures Jesus' feet washing. According to Manns, feet washing had particular significance in the synagogue, where it recalled God's apparition to Abraham under the oaks of Mamre ${ }^{26}$ in Gen 18:4, "Let a little water be brought, and wash your feet, and rest yourselves under the tree". Brown states that at least ten people were necessary for a Passover meal; he states that Mark 14:17, Matthew 26:20 mention the twelve as the disciples. Luke 22:14 made mention of "the apostles". He states that John does not mention the Twelve, but a comparison of 13:18 ("Men I choose") with 6:70 ("Did I not choose the twelve of you myself") makes it plausible that the evangelist was thinking of the Twelve. Those stated by name in the Johannine account of the meal are in the synoptic lists of the Twelve.

\section{d. Feet (v.5)}

The disciples seem to have been on couches, reclining on their feet sides. Each would use his left arm to support his head and his right arm to reach the dishes that were on a table which was placed in the center of the couches. He said Jesus would have come around the outside of the couches towards the disciples' feet which were stretched out behind them. Reclining was not the normal position at meals in a home but was customary at Passover. ${ }^{27}$ The necessity to wash the feet, for comfort and cleanliness, resulted from the dusty roads and foot-washing was a sign of hospitality, generally performed by the meanest slave. ${ }^{28}$ Washing the feet stained with the dust of the road was part of the regular duty of hospitality (Gen 8:4, Exodus 30:19, II Sam 11:8, Luke 7:44). The washing of the feet at the Last Supper is primarily

17 J. D. G. Dunn, “The Washing of the Disciples' Feet in John 13” 61, ZNW, (1970), 247.

18 H. Weiss, 'Foot Washing in the Johannine Community' 21, NOVT, (1979): 299.

19 Raymond E. Brown, The Anchor Bible: The Gospel according to John XIII - XXI. A New Translation with Introduction and Commentary (Garden City: Doubleday, 1960), 559.

20 J. N. Collins, Diakonia: Reinterpreting the Ancient Sources (Oxford: Oxford University Press, 1990), 6.

21 David Noel Freeman ed. Eerdmans Dictionary of the Bible (Michigan: Grand Rapids, 2000), 468.

${ }_{22}$ C.K. Barrett, Peake's Commentary on the Bible (London: Thomas Nelson Printers, 1967), 437.

23 Brown, 551.

24 Mary L. Cole, 407.

25 Arland J. Hultgren, “The Johannine Foot washing as a symbol of Eschatological Hospitality;” 28, NTS, (1982): 541

${ }^{6}$ This was a quote made by Mary L. Coloe in The Catholic Biblical Quarterly.

Brown, The Anchor Bible, 551.

F.F Bruce, et'al, The New Bible Dictionary (London: Intervarsity Press, 1974), 434. 
connected with this custom (John 13). Christ the Lord and Master assume the garb and does the work of a slave (13:4). ${ }^{29}$

\section{Concepts of leadership}

According to the Interpreter's Commentary of the Bible, 'a servant is a person of either sex' who is in the service of a master. He is under obligation to obey, to work for the benefit of his master and usually receive some protection in return. It is synonymous to a slave or a bondmaid, similar to the Greek word doulos meaning 'king's attendant' and again in the Greek is diakonos also meaning 'one who obeys and serves another' ${ }^{30}$ For the Son of man did come to be served but to serve and give his life as a ransom for many (Mark 10:45). Being a servant therefore is an act, a life to be lived, not a name or title to be identified with. Charles Swindoll, in Improving your Serve, notes that, "in God's family there is to be one great body of people: servants. In fact this is the way to the top in his kingdom." 31 This is humility and is what Christian leadership is, for no one can faithfully serve God's way without this singular virtue. The servant mindedness, which is humility, is what seems to be missing in leadership today. Crucial as humility is in leadership, unfortunately, there seems not to be much of the servant mentality in leadership at all levels. J.N. Collins states that the most important New Testament term for servant is Greek, diakonos, which in ancient Greek sources denotes an emissary and spokesperson of another. Paul provides the earliest and most ample evidence of this meaning in early Christianity. He described himself and Apollos as 'diakonos'(emissary), conveying that they all belong to a deity and are entrusted with the deity's message, have the commission to announce it and to have a right to be heard and believed (1Cor 3: 5, 2Cor 3: 6, 6:4). With diakonos Paul expresses his specific entitlement as an authoritative spokesman and an ambassador of God. ${ }^{32}$ According to the Synoptic Gospels, this understanding of early Christian ministry as ambassadorship comes from Jesus: "whoever wishes to become great among you must be your servant... for the Son of Man came not to be served but to serve and give his life a ransom for many" (Mark 10: 43-45). Swindoll again notes that, "The "Celebrity Syndrome' so present in Christian thought and activity just does not conform to the attitude and message of Jesus." 33 Humility is the greatest virtue that Jesus defines himself with and followers of his must demonstrates same. Leadership, however, is a process of influencing, directing people or objects towards a definite goal. Matthew Henry describes a leader (Greek; hegemon) as someone who acts as a guide, a directing head or chief. Someone or something that leads a body of moving troops or animals or congregation. ${ }^{34}$ From the description above, leadership can be defined as the position of a leader, the quality displayed by a leader and the act of leading by influencing others.

\section{The Role of Humility in Leadership}

The basic responsibility of leadership is to bring people together and this involves not only physical presence but also the spirit of common willingness. Bruce Powers, in Christian Leadership, notes that servant leadership does not function in isolation; it is with, for and through people that a person's effectiveness as a leader can be measured to a great extent by his ability to elicit, combine and focus the energy of people on achieving common goals. ${ }^{35}$ Jesus came to seek and to save those that are lost and to give his life a ransom for many (Mark 10.45). He did not come to be served, but to serve, that means he humbled himself just as (Phil. 2: 8-11) says of him. This is the type of leadership that must be emulated by all, especially those in authority and leadership, for this to be done, a paradigm shift is required. Stephen Adei in Call to Lead states, "Whiles Leadership techniques and methods may vary, there is something beneath the surface of Servant Leadership that is unchanging". ${ }^{36}$ That certainly is humility, this buttresses the resilient nature of humility in leadership and hence its importance. The gentle and humble lifestyle of the Saviour is nowhere more evident than in the account of John 13: 4-5 where he washed the feet of his friends, the disciples; this is a true demonstration of humility. In that event, he left us some timeless principles regarding servanthood that cannot be ignored. If one is serious about servant leadership, he/she must take time to learn and apply the fact as well as the implications of John 13:4-5. In the first century Jerusalem, paved roads were few; in fact, within most cities they were unheard of. The roads and alleys in Jerusalem were more like winding dirt trails, all covered with a thick layer of dust. When it rained, those paths were liquid slush, several inches of thick mud. It was the custom, therefore, for the host to provide a slave at the door of his home to wash the feet of the dinner guests as they arrived. The servant knelt with a pitcher of water, a pan and a towel and washed the dirt or mud off the feet as each guest prepared to enter the home. Shoes, boots and sandals were left at the door, a custom still prevalent the Far East. If a home could not afford a slave, one of the early arriving

\footnotetext{
29 James Hastings, Dictionary of the Bible: Complete in One Volume (New York: Charles Scribner's Sons, 1952), 268.

Wilbert F. Howard ed. The Gospel of Luke and John. The Interpreter's Bible Commentary (Nashville: Bokesburg Press, 1996), 251.

Charles Swindoll, Improving your Serve: Christ's call to Unselfish Living (London: Sidney Auckland Press 1996), 21.

2 J.N. Collins, Diakonia: Reinterpreting the Ancient Sources (Cambridge: Oxford University Press, 1990), 468.

Swindoll, Improving your Serve, 21.

Henry Matthew, Matthew Henry Commentary of the Bible (Nashville: Broadman Press, 1996), 223-5.

Bruce P. Powers, Christian Leadership: A Fresh Look at Leadership that gives Life (Nashville: Broadman Press, 1979$), 11$.

Stephen Adei, Called to Lead: Be the Leader Your Family Needs (India: Oasis International Ltd, 2007), 22.
} 
guests will graciously take upon himself the role of the house servant and wash the feet of those who came. ${ }^{37}$ What is interesting is that, none of the disciples had volunteered for that lowly task, so the room was filled with proud hearts and dirty feet. Interestingly, those disciples were willing to fight for a throne, but not a towel. Things have not changed much since then.

\section{Comparative Discussion on Humility}

John 15 verses 1-3V 1-3 point to the fact that Christ "knew that the Father has committed all things into his hands," contrary to popular belief, it is rather those who are aware and confident of who they are, those who are certain of what God has made them and given them and are sure no one can take it away from them that are humble. Pride turns to rather make a person insecure. They end up thinking by being humble they might end up losing their worth. The virtue of humility is therefore for the strong and not for the weak. I consider humility as "power under control." Hence Christ's call for humility is not to be looked mean down upon but rather embraced by his followers as servant leaders. No one who really knows Jesus could consider him as a weakling, probably the strongest man to have stepped foot on the shores of this earth, yet even though God (Phil 2:5) humbled himself. Humility also leaves an indelible footprint way after a person is even dead and gone; chapter 11 of the book of Hebrews where the giants of the spiritual hall of fame are mentioned is a case in point. It is the humble that are celebrated and remembered and not the proud and arrogant. The feet washing which demonstrated the qualities of servant leadership has deep rooted lessons one must not ignore; one of such lessons is that of humility. William Barclay observes, "in John we have always to be looking for two meanings. There is the meaning which lies on the surface, and there is the meaning which is beneath the surface. On the surface it is great and dramatic, and beneath an unforgettable lesson in humility." ${ }^{38}$ Jesus is God, a great man among men and yet he was humble. "Humility does not come easily or naturally, it takes a great man to be humble. It is the man who is truly great and truly beloved who has this legal humility which makes him both servant and king among men." ${ }^{39}$ Donald Hankey who was a beloved captain, had this said of him, and it sort of summarizes the virtue of humility, "we all knew instinctively that he was our superior, a man of finer fiber than ourselves, a 'tuff' in his own right. I suppose that was why he could be so humble without loss of dignity." ${ }^{40}$

Kenneth Gangel in Building Leaders for Church Education notes, "Evangelical leaders following the gentleness and humility of Christ recognize they are neither the single nor final authority... the pastor is the coach, not the general manager and certainly not the team owner." ${ }^{\prime 1}$ The above quote makes it clear, that leaders in Christian circles must follow the gentleness and humility of Christ if they have to remain his followers. The final authority does not lie with the leaders but with Christ, and they must clearly understand that. Jesus is the only owner of the team (his church), the pastor is at best a coach under Jesus' orders, and this is true humility. Samuel L. Brengle, in The Soul Winners 'Secret, notes, "Humility is not won by promotion, nor by many prayers and tears. It is attained by confession of sin, and much heart searching and humbling before God; by self-surrender, a courageous sacrifice of every idol, a bold uncomplaining embrace of the cross, and by an eternal, unfaltering looking unto Jesus crucified." ${ }^{\prime 2}$

Humility is not gained by seeking great things for ourselves, but like Paul indicates, by counting those things that are gain to us as loss for Christ. This is a great price, but it must be paid by the leader who would not be merely a nominal but real spiritual leader of people, a leader whose power is recognized and felt in heaven, on earth and in hell. Samuel Brengle has rightly hit the nail on the head by giving the means and ways by which humility as vital leadership value can be attained is to walk in humility as Christ did. If humility is this expensive and leaders know what it cost to be a leader in the real sense, then people would not be pushing themselves into positions of servant leader but would wait until they are called by the Lord who also would grace them to be humble. A.W. Tozer writes: a true and safe leader is likely to be one who has no desire to lead, but is forced into a position by the inward pressure of the Holy Spirit and the press of circumstance; there was hardly a great leader from Paul to the present day that was not drafted by the Holy Spirit for the task, and commissioned by the Lord, to fulfill a position he had little heart for. The man who is ambitions to lead is disqualified as a leader. The true leader will have no desire to lord it over God's heritage, but will be humble, gentle, self-sacrificing and altogether ready to follow when the Spirit chooses another to lead. ${ }^{43}$ The choice of leadership is a preserve of the Holy Spirit, the role of the servant leader is to be humble and allow God to choose and use whosoever He wants. There should be no ambition on the part of leaders; else they may not qualify for the master's use. In the words of Rogerson: "the humility of Jesus is, after all, revealed finally in his death. To understand this and

\footnotetext{
37 Swindoll, Improving your Serve, 1.

38 William Barclay, The Gospel of John Volume 2 (Edinburgh: The Saint Andrews Press, 1961), 164.

39 Barclay, The Gospel of John Volume, 162.

${ }^{40}$ Barclay, The Gospel of John Volume, 162.

${ }^{41}$ Kenneth O. Gangel, Building Leaders for Church Education (Chicago: Moody Press, 1981), 73.

42 Samuel Logan Brengle, The Soul Winner's Secret (London: Salvation Army, 1981), 22.

3 A. W. Tozer, 459.
} 
carry it through (John 13:17) is to receive God's benediction." ${ }^{44}$ Jesus' humility was manifested in his death (Philippians 2:8); a leader's role is self-denial and obedience.

\section{Leadership requires Humility}

The vv 4-5 of John 15 as indicated above clearly shows he cannot become a servant if he/she does not humble himself or herself as Jesus did in the text. Saint Francis of Assisi gave a vivid picture of the indispensable nature of humility as a character quality when he said do you want to know? Since God oversees the affairs of everyone both the sinners and righteous, he chose no least a person like me (Christ) to confront the nobility and grandeur, the strength, the beauty and the learned of this world. ${ }^{45}$ This perfectly couched the heart language of every true and humble leader; though they have accomplished something, they know it was not by might, nor by power but by the spirit of the most high; nevertheless, they are grateful God had considered them worthy vessels to be used by him, and this they are eternally grateful for. John Mott captured well the heart of spiritual leadership: Leadership is a maximum service of unselfishness and fullhearted observation in the kingdom building of Christ. ${ }^{46}$ The heart must be made willing by the individual who must be a servant leader. This together with the mind must be placed on the altar of sacrifice for the Lord to work on as a vessel of honor meet and sanctified for the master's use, and prepared unto every good work. It takes the Spirit of God for any leader to cultivate a heart of humility; it is not possible without his help much the same way as a carmel going through the eye of a needle.

Samuel L. Brengle states it this way:

"Oh for teachers among us; leaders who know how to read hearts and apply truth to the needs of the people as a good physician read patients and apply remedies to their ills. There are soul-sicknesses open, and obscure, acute, and chronic, superficial and deep-seated diseases which the truth in Jesus will heal. But it is not the same truth for each need, any more than the same medicine for every disease. That is why we should most diligently study the Bible and pray for the consistent and powerful illumination of the spirit". ${ }^{47}$

William Law writes in his devotional classic Serious Call; let every day be a day of humility; condescend to all the weaknesses and infirmities of your fellow creatures, cover their frailties, love their excellences, encourage their virtues, relieve their wants, rejoice in their prosperities, compassionate in their distress, receive their friendship, overlook their kindness, forgive their malice, be a servant of servants, and condescend to do the lowliest offices of the lowest of mankind..$^{48}$ It is only humility in its true sense that takes pride, the number one enemy of humility, from our hearts in order to treat our fellow humans equally and with fairness. Samuel Brengle put it beautifully, "If I appear great in their eyes, the Lord is most graciously helping me to see how absolutely nothing I am without him, and helping me to keep little in my own eyes. He does use me. The axe cannot boast of the tree it has cut down. It could do nothing but for the woodman. He made it, he sharpened it, and he used it. The moment he throws it aside; it becomes only old iron. Oh that I may never lose sight of this." ${ }^{\prime 49}$ If a leader achieves any feat, it is the Lord that must be praised, and this, servant leaders must never forget in their quest to lead the flock of God, humility the moral high ground leaders must thread.

\section{CONCLUSION}

In view of the above discourse, it is essential that leaders should examine themselves and find out if humility is really being exhibited in their leadership responsibilities. This is imperative for successful leadership. Perhaps through this form of self-assessment every individual gets improvement in their career. One may begin as following any of these leadership styles: Reward Power Leadership, Coercive Power, Legitimate Power, Expert Power Leadership, Referent Power. Yet if every leader wants to be successful, humility must be yearned for and embraced.

From this exposition Jesus displayed the vital trait he used to propagate the Gospel to all his disciples. It must also be humanity's desire to let this trait of humility be used and displayed to the entire humanity. This is how humanity can benefit from the work of leadership, thereby leading in truth to make the necessary impact on others. Humility is the virtue all leaders must embrace, to ensure true leadership by example. Going forward this paper proposes that should all go the way of humility, leadership at all levels would make so much impact at both Christian and secular levels. This theological discourse on humility as Jesus portrayed must be the path to thread upon by all leaders and those who aspire to become leaders.

44 James D. G. Dunn \& John W. Rogerson eds, Eerdmans Commentary on the Bible (Grand Rapids: William B. Eerdmans Publishing Company, 2003), 68 .

45 James Burns, Revivals, their Laws and Leaders (London: Hodder \& Stoughton, 1905), 95.

46 John B. Mott, The Burning Heart (London: S. C. M Press, 1934), 353.

47 C. W. Hall, Samuel L. Brengle, The Illuminator (New York: Salvation Army, 1933), 112.

${ }_{48}$ William Law (1686 - 1761) was an evangelical devotional writer and mystic. He is best known for a serious call to a devout and holy life (1728)

${ }^{49}$ C. W. Hall, Samuel L. Brengle, The Illuminator (New York: Salvation Army, 1933), 275. 


\section{Bibliography}

Adei, Stephen. Call to Lead: Be the Leader Your Family Needs. India: OASIS International Ltd, 2007

Barclay, William. The Letters of Peter and Jude. Edinburgh: St.Andrew, 1958.

Barrett, C.K. Peake's Commentary on the Bible. London: Thomas Nelson Printers, 1967.

Brengle, L. Samuel. The Soul Winner's Secret. London: Salvation Army, 1918.

Brown, E. Raymond \& Paul J. Achtemier. Mary in the New Testament New York: Paulist Press, 1978.

Brown, E. Raymond. Does the New Testament Call Jesus God? Theological Studies. Garden City, N.Y: Doubleday, 1965.

Brown, E. Raymond. The Gospel according to John I-XII. Garding City, N.Y: Doubleday, 1960.

Brown, E Raymond. The Gospel according to John XIII-XXI. Garding City: Doubleday and Co, 1970.

Brown, E. Raymond. Introduction to the New Testament. New York: Anchor Bible, 1997.

Brown, E. Raymond. The Community of the Beloved Disciple. New York: Paulist Press, 1979.

Bruce, F.F. The Gospel of John. United States of America: Erdmann's, 1994.

Coloe, L. Mary. God Dwells with us: Temple Symbolism in the Fourth Gospel. Collegeville, MN: Liturgical Press, 2001.

Coloe, L. Mary. "Welcome into the Household of God: The Foot Washing in John 13, in The Catholic Biblical Quarterly 66, no. 3, (2004): 400-415.

Collins, J.N. Diakonia: Reinterpreting the Ancient Sources. Oxford: Oxford University Press, 1990.

Dunn James D. G. \& Rogerson John W. eds, Eerdmans Commentary on the Bible. Grand Rapids: William B. Eerdmans Publishing Company, 2003.

Gangel, O. Kenneth. Building Leadership for Church Education. Chicago: Moody Press, 1987.

Hasting, James. Dictionary of the Bible: Complete in one Volume. New York: Charles Scribner's Sons, 1952.

Henry, Mathew. Commentary on the Whole Bible Complete and Unabridged in one Volume U.S.A: Hendrickson Publishers, 1991.

Hill, Charles. The Johannine Corpus in the Early Church. New York: University Press, 2004.

Mott, Mathew. The Burning Heart. London: S.C.M Press, 1934.

Powers, Bruce. Christian Leadership: A Fresh Look at Leadership That Gives Life. Nashville, Tennessee: Broadman Press, 1979.

Sanders, J. Oswald. Spiritual Leadership: The Principle of Excellence for every Believer. Chicago: Moody Bible Institute, 1980.

Swindoll, R. Charles. Improving your serve: Christ call to Unselfish living. London: Sydney Auckland Press, 1996.

Weiss, H. 'Foot Washing in the Johannine Community' 21, NOVT, (1979): 299.

Williamson, S.G. Akan Religion and the Christian Faith. Accra: Ghana University Press, 1969. Accessed on Saturday March 30, 2020 https:/expertprogrammanagement.com/2017/06/the-5-types-of-power/ http://profmsr.blogspot.com, Accessed on June 11, 2020

http://en.wikipedia.ogr/wiki/humility, Accessed October 22, 2019.

www.merriam-webster.com, Accessed 11 June 2020. 